\title{
Research on Off-Grid Photovoltaic System Under Non-Linear Condition Using Solar GIS Tool
}

\author{
Jitendra Kumar Saroj, Rajesh Kumar
}

\begin{abstract}
This paper proposes a novel method for the analysis of photovoltaic system under unreliable condition. The photovoltaic system is the combination of large number of PV cells connected in series. The photovoltaic system plays a great role in reducing the global warming and maintaining the ecological balance by promoting to the green environment. The photovoltaic system replaces the conventional method of generating electricity to the non-conventional method of generating electricity. This paper focus on distinguishing the performance of photovoltaic system under uniform condition and non-uniform unreliable condition through the solar GIS tool.
\end{abstract}

Keywords- Photovoltaic cell, unreliable condition, solar GIS tool.

\section{INTRODUCTION}

With the rapid increase in power consumption, it is very difficult for utility system to fulfil the demand of customer loads [1]. In the electrical power system from generating station to distribution system there arises multiple losses thereby reducing the voltage profile of whole power system [2],[3]. Nowadays to meet the energy demand the utility power system is coupled with the renewable energy resources for fulfilling the energy demand as well as making the pollution free environment [4]. The main advantage of using photovoltaic cell for generating electricity is that it is eco-friendly, pollution less, simple in design, reliable, durable and most efficient [5],[6]. Sun is gives energy almost in every geographical region, therefore the energy of sun can be easily extracted and converted into electricity by simply employing PV cells. Single PV cell produces only $0.7 v$, so on combining multiple photovoltaic cell the array is formed that generates high power of electricity [7],[8].

There are many factors on which the efficiency of solar PV is dependent such as temperatures, pressure, height of installation, light intensity, climatic conditions and partial shading [9]. The temperature plays an important role for improving the efficiency of the solar cell. On reducing the temperature more current will be generated thereby improving the efficiency of the system [10]. During winter times the intensity of sun is low and the efficiency of the solar PV system reduces. It is to be noted that the efficiency of the solar PV is not reduced due to the low temperature but due to low intensity of sun falling on the PV array. Secondly, if the height on installation is high than solar PV will generate more

Revised Version Manuscript Received on 10 September, 2019.

Jitendra Kumar Saroj, Department of Electronics \& Communication India. (Email: researchnietip@gmail.com)

Dr. Rajesh Kumar, Department of Physics, Noida Institute of Engineering and Technology, Noida, U.P. India. (Email: researchnietip@gmail.com) Engineering, Noida Institute of Engineering and Technology, Noida, U.P.

power and if the setup is installed at low height then there may be low generation of electricity due to heating effect. Therefore, in this paper a performance analysis is done for off grid photovoltaic array system under different operating conditions.

\section{ANALYSIS OF OFF-GRID SOLAR PV SYSTEM}

The PV system is basically an off grid solar PV array which do not require any external power supply from the electrical grid to power the houses of different customers. The PV array gives electricity directly to the homes or offices [11]. It comprises of a PV array, wherein the array is made up of large number of amorphous crystals connected in series, a battery for storing the generated electrical current, a charge controller for preventing the battery from over charging, a power conditioner attached to the PV array to convert the generated DC power into ac power so that it could be used directly by the customers. During night times the power which is stored in the battery can be used to power the houses.

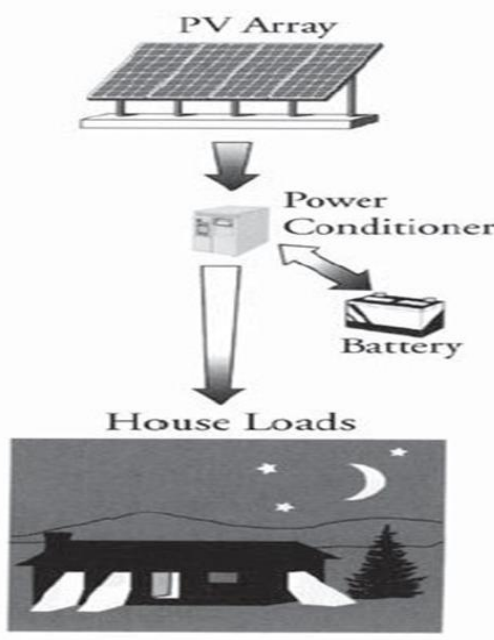

Fig.1 off-Grid PV System

\section{- Solar GIS Tool}

The analysis of solar PV system can be done through the software known as solar GIS tool. Solar GIS tool is basically a simulation software that is very much popular nowadays. This software provides a detail analysis performance of solar PV array under normal operating as well as nonlinear operating conditions. solar GIS tool is pc software package that is used for studying, sizing simulation and data analysis of complete PV system [12]. It measures the size of solar
Blue Eyes Intelligence Engineering \& Sciences Publication 


\section{RESEARCH ON OFF-GRID PHOTOVOLTAIC SYSTEM UNDER NON-LINEAR CONDITION USING SOLAR GIS TOOL}

panel, determines the height of installation, analyse theproduced data. This tool can also be used for examine the different load data of the system and estimate the total energy production in the system. The evaluated energy production data can be hourly, weekly, monthly or yearly performance. Solar GIS tool calculates the total estimation for installing the solar PV system according to the customer needs.

\begin{tabular}{|c|c|c|c|c|c|}
\hline $\begin{array}{c}\text { Appliance } \\
\mathrm{s}\end{array}$ & $\begin{array}{c}\text { Rated } \\
\text { wattage }\end{array}$ & $\begin{array}{l}\text { Adjustment } \\
\text { factor }\end{array}$ & $\begin{array}{c}\text { Adjusted } \\
\text { wattage }\end{array}$ & $\begin{array}{c}\text { Hours/d } \\
\text { ay used }\end{array}$ & Energy/day \\
\hline $\begin{array}{c}30 \mathrm{~W} \\
\text { light (5) }\end{array}$ & 150 & 0.85 & 176 & 2 & 352 \\
\hline $\begin{array}{c}45 \mathrm{~W} \text { fans } \\
\text { (3) }\end{array}$ & 135 & 085 & 588 & 5 & 2940 \\
\hline Refrigerator & 500 & 0.85 & 159 & 8 & 1272 \\
\hline $\begin{array}{l}\text { Washing } \\
\text { machine }\end{array}$ & 1500 & 0.85 & 1765 & 0.86 & 1518 \\
\hline Television & 200 & 0.85 & 235 & 4 & 940 \\
\hline $\begin{array}{c}\text { Microwave } \\
\text { oven }\end{array}$ & 1500 & 0.85 & 1765 & 0.25 & 441 \\
\hline
\end{tabular}

\begin{tabular}{c|c} 
& $\begin{array}{c}\text { Gl. horiz. } \\
\mathrm{kWh} / \mathrm{m}^{2} \text {. day }\end{array}$ \\
\hline Jan. & 5.66 \\
Feb. & 6.16 \\
Mar. & 6.54 \\
Apr. & 6.07 \\
May & 5.49 \\
June & 4.57 \\
July & 5.12 \\
Aug. & 5.47 \\
Sep. & 5.72 \\
Oct. & 5.36 \\
Nov. & 4.82 \\
Dec. & 5.18 \\
\hline Year & 5.51
\end{tabular}

Fig.2 Monthly irradiance data

The above figure shows the estimation for the total load of the customer's house. It includes total number of different electrical appliances consuming energy along with their rated wattage and appliances running hours per day. By inserting above mentioned data the solar GIS tool calculate the total energy demand per day. Fig. 2 shows the monthly irradiance data which is based on each month energy consumption data and after summing up it shows the total energy consumed in one year. Fig.3 shows the graph of hourly data representing the increment of power generation from solar PV array as the intensity increases from morning to noon time. And after certain period of time the power start decreasing. Fig.4 represent the tilting and orientation of PV system and helps the user to install the solar PV array in a particular axis where the maximum power tracking is received by the system.

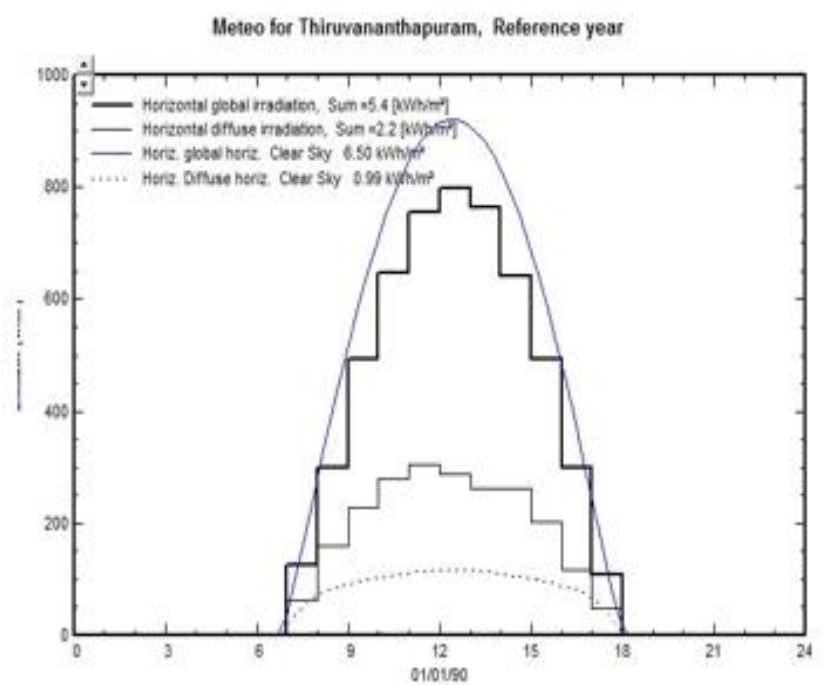

Figure.3 Graphs of Mateo hourly data

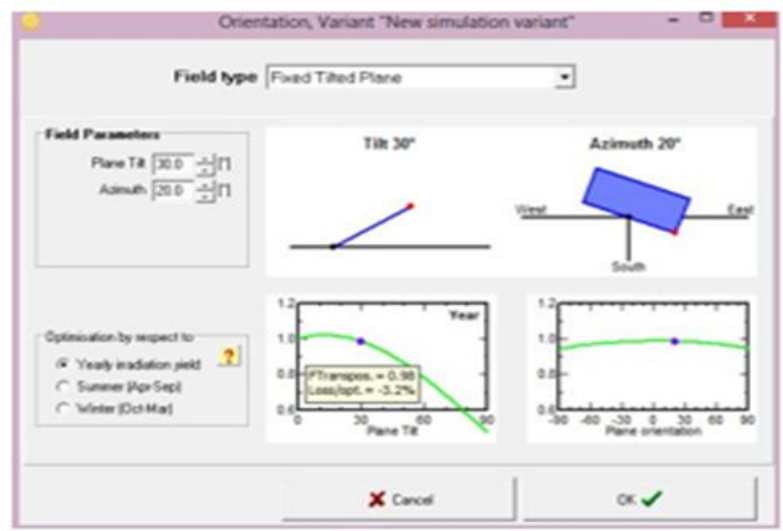

Figure 4. Tilting and orientation of PV panel

\section{SIMULATION RESULTS}

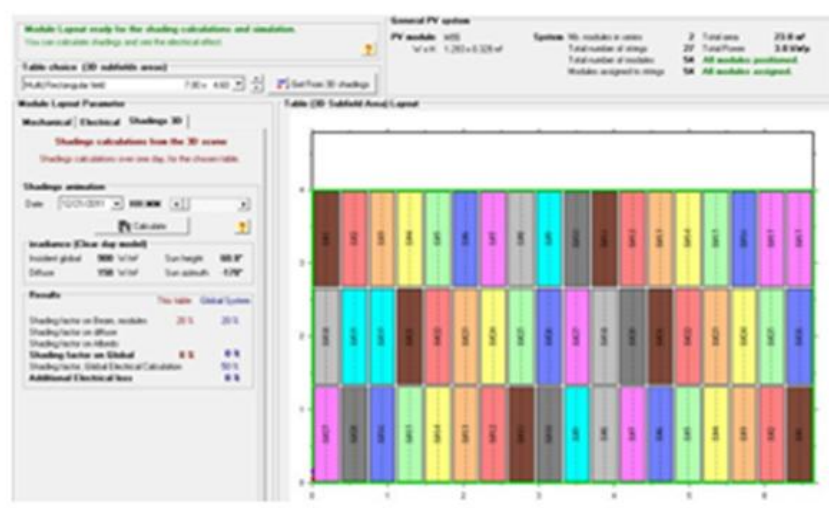

Figure 5. Module layout with shading

In order to obtained the simulation firstly, the design of solar PV system is made by connecting the block in the solar GIS tool software. Figure.5 represent model layout with shading condition for the month starting from January to December. It determines the maximum sun tracking position for each month and allows the customer for selecting the better axis for installing the solar panel. 


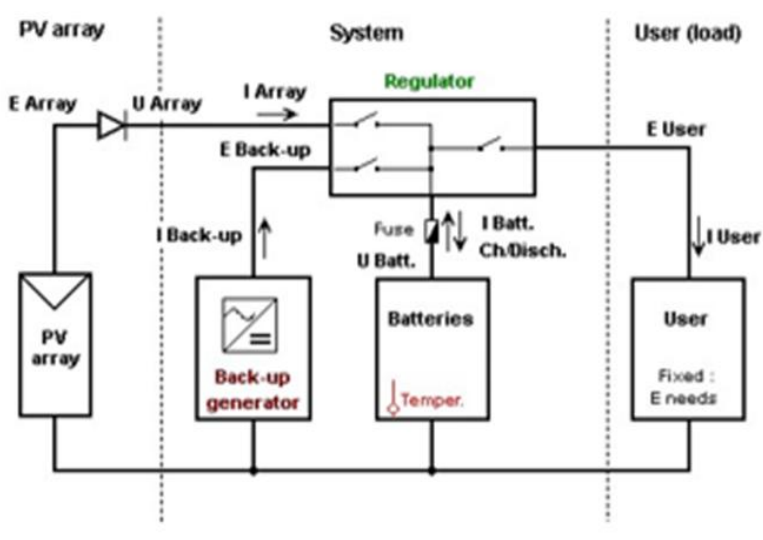

Figure 6. Schematic of the system

Fig. 6 represent the schematic block diagram of solar PV system. In this system firstly the solar panel is fixed at maximum power point tracking axis i.e. 23 degree and after detecting the solar light intensity the solar array generates the electrical power. This generated power is further transferred to the battery for storing and using it during night times.

The generated power can be used directly by the customers during day time by converting the power from dc to ac through the inverter. It is to be noted that we have generated partial shading condition for obtaining different operating characteristics of solar PV array. After proper coding in the software the software is run to obtained the characteristics under partial shading condition as shown in fig.7 (a) and (b).
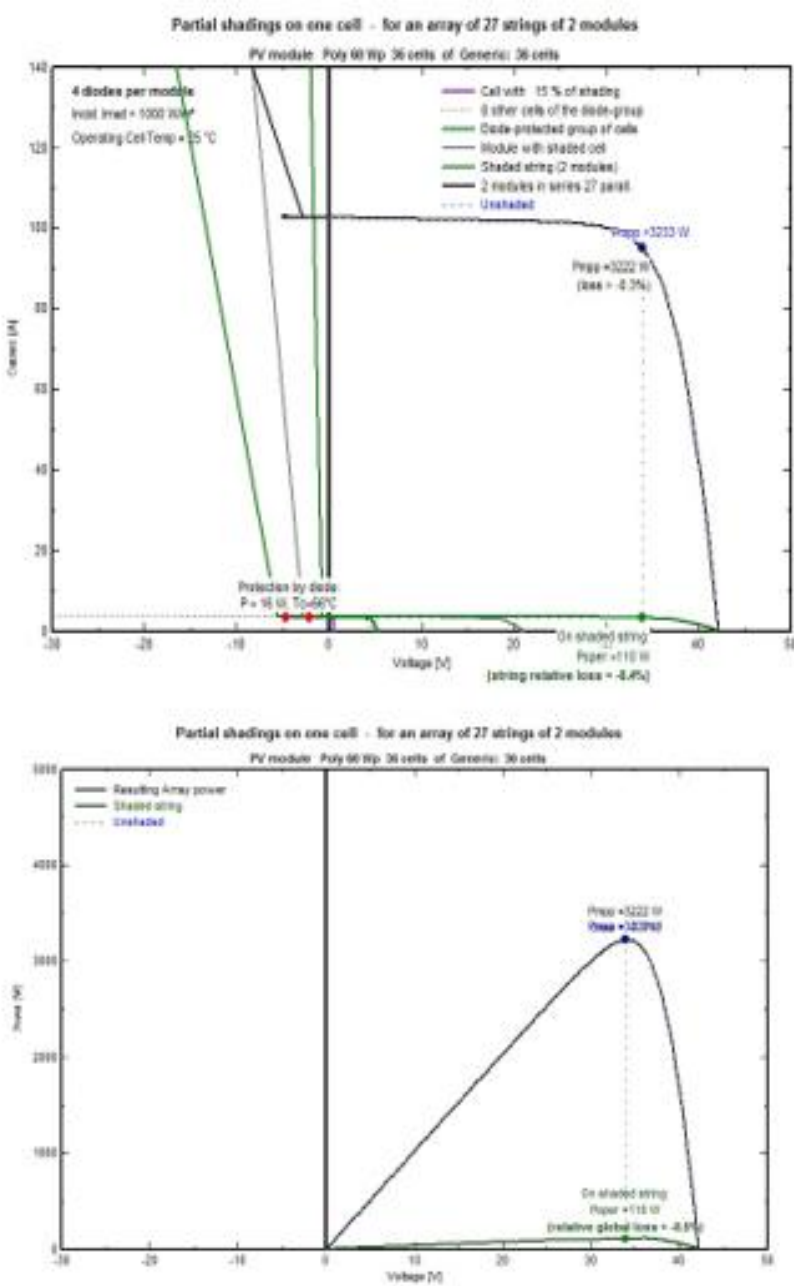

Figure 7. I-V and P-V curve under partial shading conditions

\section{CONCLUSION}

The designing and testing of off- grid solar pv system is successfully done through the solar GIS tool software. The main purpose of this paper is to determine the efficiency of the solar PV system under partial shedding condition and to determine the sizing, simulation and data analysis of complete PV system. It is concluded that by using solar GIS tool the size of solar panel which is to be installed, energy consumption rate of customers loads and the maximum power point tracking is achieved. It is also noted that during partial shedding condition the efficiency of the solar PV system is reduced as compared to the uniform condition. This software also gives the detail description of total losses occurs after production of electrical power.

\section{REFERENCES}

1. C. W. Gellings, "The Concept of Demand-Side Management for Electric Utilities,” Proc. IEEE, 1985.

2. A. Grandjean, J. Adnot, and G. Binet, "A review and an analysis of the residential electric load curve models," Renewable and Sustainable Energy Reviews. 2012.

3. M. Pipattanasomporn, M. Kuzlu, S. Rahman, and Y. Teklu, "Load profiles of selected major household appliances and their demand response opportunities," IEEE Trans. Smart Grid, 2014.

4. E. Benedict et al., "Losses in Electric Power Systems," 1992.

5. R. Lauge-Kristensen, "Renewable energy," in Sustainable Practices in the Built Environment, Second Edition, 2008.

6. P. Bajpai and V. Dash, "Hybrid renewable energy systems for power generation in stand-alone applications: A review," Renewable and Sustainable Energy Reviews. 2012.

7. R. Sen and S. C. Bhattacharyya, "Off-grid electricity generation with renewable energy technologies inIndia: An application of HOMER," Renew. Energy, 2014.

8. T. Khatib, I. A. Ibrahim, and A. Mohamed, "A review on sizing methodologies of photovoltaic array and storage battery in a standalone photovoltaic system," Energy Conversion and Management. 2016.

9. M. E. Meral and F. Diner, "A review of the factors affecting operation and efficiency of photovoltaic based electricity generation systems," Renewable and Sustainable Energy Reviews. 2011.

10. C. Lamnatou and D. Chemisana, "A critical analysis of factors affecting photovoltaic-green roof performance," Renewable and Sustainable Energy Reviews. 2015.

11. S. Baurzhan and G. P. Jenkins, "Off-grid solar PV: Is it an affordable or appropriate solution for rural electrification in Sub-Saharan African countries?," Renewable and Sustainable Energy Reviews. 2016.

12. J. M. Sánchez-Lozano, J. Teruel-Solano, P. L. Soto-Elvira, and M. Socorro García-Cascales, "Geographical Information Systems (GIS) and Multi-Criteria Decision Making (MCDM) methods for the evaluation of solar farms locations: Case study in south-eastern Spain," Renewable and Sustainable Energy Reviews. 2013. 